\title{
Macedonia's exports and the gravity model
}

\author{
Dushko Josheski Mico Apostolov
}

\section{Abstract}

This paper examines the export performance of the Republic of Macedonia to its main trading partners; hence we focus on the major importing countries which are most present in the Macedonian trade balance.

The data used in this article are analyzed with gravity model, which has good characteristics and very stable performance. Further, the data sample is formed on the Balkan countries i.e. Albania, Bosnia and Herzegovina, Bulgaria, Croatia, Greece, Romania, Slovenia, Turkey and Serbia and Montenegro.

The results show that the domestic country GDP is positively correlated with the exports from the source country to target countries and that Balkan countries have positive propensities to import from Macedonia, however it was found that populations of source country and target country are negatively correlated with exports from the source country to target countries. Additionally, the business cycles had no positive effect on Macedonian export to the target countries.

JEL Classifications: E30, F10, O10, P20

Keywords: exports, gravity model, Macedonia 


\section{Introduction}

\section{Theoretical and literature framework}

The gravity model has good characteristics and very stable performance throughout the long time line of research on foreign trade flows. Further, the basics of this analysis were set on the grounds of the relation between gross domestic product (GDP) and bilateral trade flows (Tinbergen, 1962).

Supplementary advances were made especially in the aria of product differentiation (Anderson, 1979) and competition models based on monopolistic structures, in addition to, increasing returns to scale (Helpman \& Krugman, 1987). Deardorff has made serious advances while proving that the gravity model can be validated from standing point of standard trade theories (Deardorff \& Research, 1995).

At length, the latest significant developments of the gravity model use are progressed towards operational gravity model that was derived as a consequence of extended research and manipulation of the constant elasticity of substitution (CES) preferences and goods i.e. CES expenditure system by Anderson and Wincoop in order to solve the border puzzle (Anderson \& Wincoop, 2003).

\section{Trade and Exchange Rate}

The literature focuses on two basic directs through which trade can be affected by the movements in the exchange rate, most prominently the environment of uncertainty as well as the political economy factors (Decker \& Lim, 2009; Frankel \& Romer, 1999; Meeusen, 1999).

a) The first assumption is that the trading firms and their answer to the environment of uncertainty depend on the degree of risk aversion. Hence, two basic responses can be observed due to risk aversion in uncertainty. The first reaction is substitution, a situation where greater uncertainty discourages them to move into riskier deals and thus affects 
international trade negatively. The second is defined by the income effect, where there is constant intention to increase international trade in order to counterbalance the deterioration in total expected utility (Grauwe, 1988). Further, it is estimated that when there is a case of increased risk aversion the latter situation prevails, however it must be noted that the conclusions on the size of trade volumes is ambiguous (Dellas \& Ben-Zion, 1993).

b) The ambiguity of the uncertainty effects and the negative outcomes produced by exchange rate variability pushes the thought to deduction that another mechanism might be more influential while determining the volume of the trade. Consequently, it is claimed that more prominent are the political economy factors (Grauwe, 1996; Grauwe, 1988). Over-valuations subdued to upshots of the political actors and the overall economic environment tend to produce protectionist behavior, which is a result of reduced output and employment, hence loss of competitiveness (Williamson, 1983). Further, it is noted that protectionist forces are shaped mainly by political ideologies influencing the institutions to react on exchange rate volatility.

\section{Bilateral trade flows and the gravity model}

The use of gravity models in empirical research concerning international trade have been used increasingly to analyze different classes of trade theories, such as factor-endowment theories, increasing returns to scale, incomplete specialization models, exchange rate variability, currency unions, regional versus multilateral trade agreements, etc.

This paper focuses on gravity model that it is important to country-specific trade (Anderson \& Wincoop, 2003) and especially bilateral trade flows. Therefore, we use country-specific dummies in order to examine country-specific trade resistance in the case of Macedonia and its bilateral most significant flows with neighboring partners.

Further, the study measures economic development as given by or the growth rate of gross domestic product (GDP). It is noteworthy to mention that trade boosts growth, as well as, 
improvements in the quality of domestic institutions which underpin economic activity (Baier \& Bergstrand, 2007; Dollar \& Kraay, 2003; Frankel \& Romer, 1999; Rodrik, 2002)

Thus, the results of our research are in line with these claims. Indeed, the importance of nongeographical determinants of trade, the article tends to give support to those who regard opening of the trade regime as a good step forward for enhanced economic activity.

\section{Macedonia and exports}

The degree of bilateral trade between countries taken under consideration, their relative location to each other, institutional quality and implemented trade policies are best analyzed by introduction of adopted gravity model such as in this case (Evenett \& Keller, 2002). The regional econometric studies show that transition economies have a degree of openness that is significantly different from that in other regions (Freinkman, Polyakov, \& Revenco, 2004). With respect to the endogeneity issue, it has been found that it could be stronger for developing countries (Frankel, 2008), as un our case, Macedonia.

Figure 0.1 Table Exports by destination, 2005 (2005 is index=100 in publications by State Bureau of Statistics of Macedonia)

\begin{tabular}{lc}
\hline Country & percent of total exports \\
& \\
Serbia and Montenegro & 20.2 \\
Germany & 19.1 \\
Greece & 8.4 \\
USA & 8.1 \\
Italy & 6.8 \\
Bulgaria & 4.4 \\
Croatia & 4.1 \\
Netherlands & 3.4 \\
Slovenia & 3.3 \\
Switzerland & 2.6 \\
Total & 80.3 \\
of which EU countries & 48.0 \\
Balkan peninsula countries & \\
\hline
\end{tabular}

Source: National Bank of the Republic of Macedonia 
From the previous Table one can see that our biggest trading partner(importer of our goods and services) is Serbia by 20.2 of our exports , followed by Germany with 19.1 percentage realization of our exports. Greece and USA are also good for our exports they participate with 8.4 i.e. 8.1 percent in our exports. Bulgaria is already in EU (but it wasn't in 2005, it is EU member since 2007) and participates (NBRM, 2012).

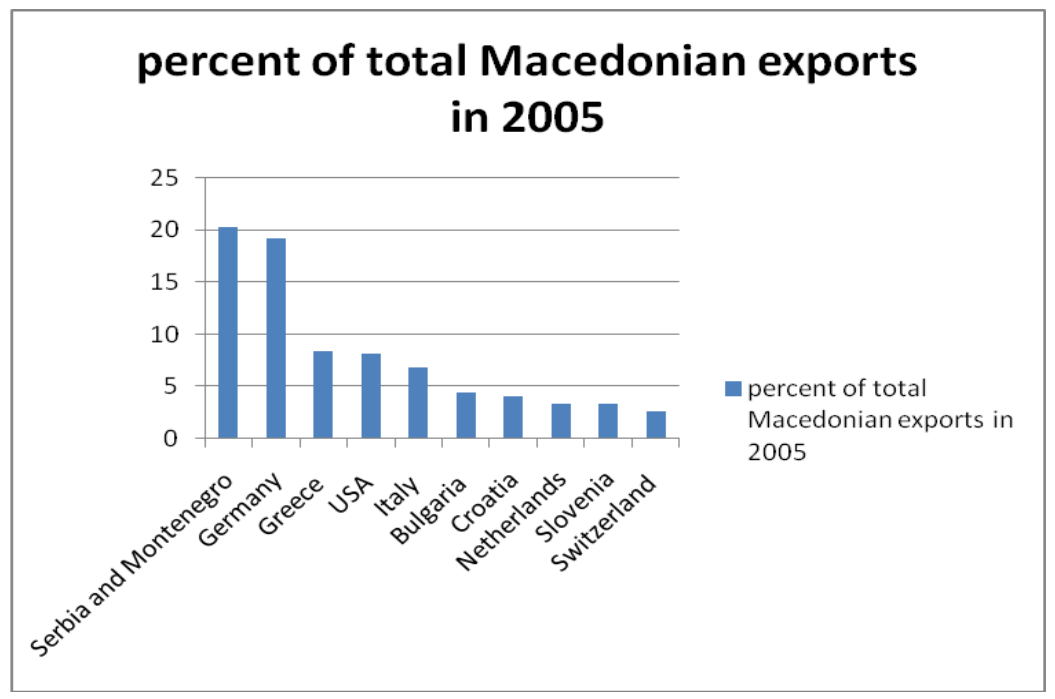

From the previous graph we can see that Serbia and Montenegro in 2005 received greatest part of Macedonia's export of goods and services.

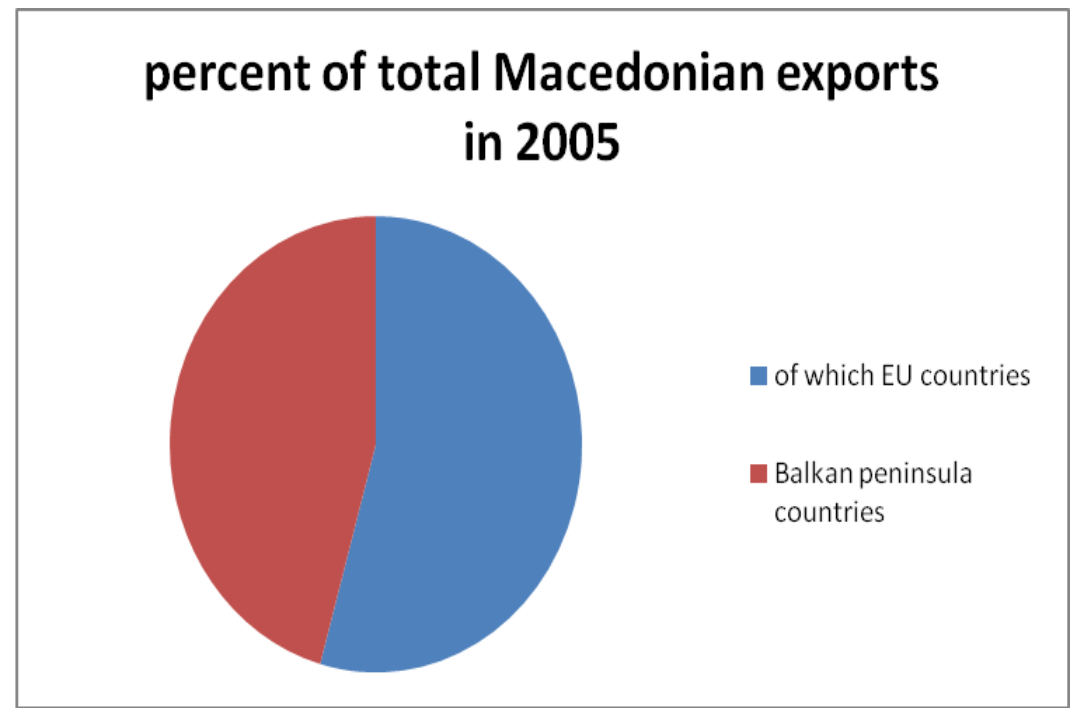


From the previous pie chart, Balkan Peninsula countries altogether with EU countries received most of Macedonia's exports of goods and services.

\section{Analytical Framework}

\section{Modeling Framework}

\section{Sample selection and Data}

In this paper we use data on Balkan countries i.e. Albania, Bosnia and Herzegovina, Bulgaria, Croatia, Greece, Romania, Slovenia, Turkey and Serbia and Montenegro i.e. Yugoslavia. Macedonia is an exporting country. This means that in our data set are all 10 Balkan countries and it covers period from 1993 to 2006. ${ }^{1}$ The data set used here was compiled from 'International Monetary Fund's Direction of Trade Statistics' data set. (IMF, 2012).

Data contained here describe export from Macedonia to source countries, Population in Macedonia and source countries, Macedonian and target country's GDP, and Exchange rates ratio.

\section{Model and Econometrics}

The gravity model that we take under consideration and use with variations has long been used (Anderson \& Wincoop, 2003; Helpman, Melitz, \& Rubinstein, 2008; Martinez-Zarzoso, 2003). We use basic gravity model extended by exchange rate which is proxy for prices:

$$
X_{i j t}=\beta_{0}+\beta_{1} X_{i j t-1}+\beta_{2} Y_{i t}+\beta_{3} Y_{j t}+\beta_{4} P O P_{i t}+\beta_{5} P O P_{j t}+\beta_{6} E R_{i j t}+\gamma_{j}+\lambda_{t}+u_{i t}
$$

Where:

\footnotetext{
${ }^{1}$ International Monetary Fund's Direction of Trade Statistics [ http://www.imf.org/external/data.htm ]
} 
1. $X_{i j t}$-is the volume of exports from source country (Macedonia) country i to country $\mathrm{j}$ ( Balkan countries i.e. Albania, Bosnia and Herzegovina, Bulgaria, Croatia, Greece, Romania, Slovenia, Turkey and Serbia and Montenegro i.e. Yugoslavia) in year t,

2. $\beta_{0}$-is the intercept and $\beta$ 's $1-6$ unknown response coefficients,

3. $X_{i j t-1}-$ is the volume of exports from source country (Macedonia) country $\mathrm{i}$ to country $\mathrm{j}$ ( Balkan countries i.e. Albania, Bosnia and Herzegovina, Bulgaria, Croatia, Greece, Romania, Slovenia, Turkey and Serbia and Montenegro i.e. Yugoslavia) in year t-1,

4. $Y_{i t}$-is the domestic country's i GDP in year t,

5. $Y_{j t}$-is the target country's $\mathrm{j}$ GDP in year $\mathrm{t}$,

6. $P O P_{i t}$-is the domestic country's i population in year $\mathrm{t}$,

7. $P O P_{j t}$-is the target country's j population in year $\mathrm{t}$,

8. $E R_{i j t}$-is the real exchange rate between countries $\mathrm{i}$ and $\mathrm{j}$ in year $\mathrm{t}$,

9. $\gamma_{j}$-are the target countries effects, which allow for countries to have different propensities to import,

10. $\lambda_{t}$-are the business cycle time effects,

11. $u_{i t}$-are the usual white standard errors,

12. $\mathrm{i}=1 . ., 126, \mathrm{t}=1993, \ldots .2006$, number of panels is 9 , and number of observations per panel is 13. $\mathrm{j}=\mathrm{N}+1$ where additional country is omitted from the regression and used as benchmark variable. Here we are going to set up a standard panel gravity model:

13. $\beta_{1}=\gamma_{j}=0, \forall \mathrm{j}$ this yields standard panel gravity model .And $\beta_{1}=\gamma_{j}=\lambda_{t}=0$ simple OLS restricted model. And this model with country and time effects $\beta_{1}=\gamma_{j}=\lambda_{t} \neq 0$ 


\section{Results and Effects}

\section{Fixed effects results}

Here for comparison we use OLS with dummies (for country and year) and IV instrumental variable estimation with country and year (business cycle effects). First, we will present basic OLS restricted model- no country or time effects.

Model 1. Simple OLS results; Model a) $\beta_{1}, \gamma_{j}, \lambda_{t}=0$ for all $\mathbf{i}, \mathbf{j}$, and $\mathbf{t}$.

\begin{tabular}{llc}
\hline Variables & Parameter estimate & $\mathrm{t}$-statistic \\
POPit & -0.7289122 & -3.37 \\
POPjt & -0.0030938 & -5.72 \\
Yit & 0.0172689 & 3.24 \\
Yjt & 0.0003559 & 5.05 \\
ERij & -11.44932 & -2.99 \\
cons & 1319.933 & 3.47 \\
RSS & \multicolumn{2}{c}{195340.639} \\
$\bar{R}^{2}=0.3814$ & $\mathrm{~N}=9, \mathrm{~J}=10, \mathrm{~T}=1993-2006$ \\
\hline
\end{tabular}

Next we present OLS with dummies model and IV with cross-country and time effects and the first effects is that using IV does not effects the result dramatically which implies that endogeneity is not a problem. 
Model 2. OLS with dummies and IV results ; Model b) $\beta_{1}, \gamma_{j}, \lambda_{t} \neq \mathbf{0}$

\begin{tabular}{|c|c|c|}
\hline & $\begin{array}{l}\text { OLS with } \\
\text { dummies }\end{array}$ & IV \\
\hline \multirow{3}{*}{ POPjt } & \multicolumn{2}{|c|}{ Parameter estimate } \\
\hline & $-0.01016746^{*}$ & - \\
\hline & & $0.01018851 *$ \\
\hline POPit & -0.4558145 & 0.00075018 \\
\hline Yit & 0.01601311 & 0.00484616 \\
\hline Yjt & $0.00042581 *$ & $0.00041873 *$ \\
\hline ERij & 8.6633183 & 11.069306 \\
\hline cons & 772.11389 & l \\
\hline Bosnia and & 14.121118 & 17.42987 \\
\hline \multicolumn{3}{|l|}{ Herzegovina } \\
\hline Bulgaria & $93.077634 * * *$ & $93.740834 * * *$ \\
\hline Croatia & $59.930817 * * *$ & $63.352013 * * *$ \\
\hline Greece & $73.009589 * *$ & $79.681773 * *$ \\
\hline Romania & 142.84847 & 144.07445 \\
\hline Slovenia & 16.901758 & 15.344228 \\
\hline Turkey & 458.51298 & 465.57857 \\
\hline $\begin{array}{l}\text { Serbia and } \\
\text { Montenegro }\end{array}$ & 6.4198219 & 2.2716456 \\
\hline
\end{tabular}




\section{Model 2 continued}

\begin{tabular}{|c|c|c|}
\hline \multicolumn{3}{|c|}{ dummies } \\
\hline & \multicolumn{2}{|c|}{ Parameter estimate } \\
\hline 1994. & 15.457416 & base \\
\hline 1995. & 12.038714 & -5.2421032 \\
\hline 1996. & -0.87274568 & -22.723828 \\
\hline 1997. & 3.225081 & -23.770992 \\
\hline 1998. & 3.6889583 & -25.051756 \\
\hline 1999. & -6.6818547 & $-31.451186^{*}$ \\
\hline 2000 & -10.735294 & $-32.894009 *$ \\
\hline 2001. & -8.4603415 & $-34.787963 *$ \\
\hline 2002. & -11.799716 & $-39.177387 * *$ \\
\hline 2003. & -3.9610424 & $-32.401343 *$ \\
\hline 2004. & .35420805 & -22.300789 \\
\hline 2005. & omitted & -11.709633 \\
\hline 2006. & omitted & omitted \\
\hline $\bar{R}^{2}$ & 0.45 & 0.44 \\
\hline RSS & 147394.032 & 392522.1 \\
\hline & $=10, \mathrm{~T}=1993-2$ & \\
\hline
\end{tabular}

Omitted country from the analysis is Albania, and omitted year is 1993

legend: $* \mathrm{p}<0.05 ; * * \mathrm{p}<0.01 ; * * * \mathrm{p}<0.001$ 
A test for joint significance of time, target and country effects.

A test for the null hypothesis $\mathrm{H}_{0}: \beta_{1}=\gamma_{j}=\lambda_{t}=0 \forall \mathrm{I}, \mathrm{j}$ and $\mathrm{t}$ can be undertaken.

$$
F=\frac{\left(R S S_{R}-R S S\right) /(N+J+T-3)}{R S S /(N J * T-N-J-T-K+3)}
$$

And for 30 and 1224 degrees of freedom critical value of $\mathrm{F}$ statistics is 1.46 the calculated $\mathrm{F}$ statistics of 13.272 clearly rejects the null hypothesis of non significance of dummy variables. This means that any inference based on the model 1 will be invalid. $\mathrm{K}$ are the parameters that are estimated not including dummy variables but including intercept $\mathrm{K}=6$. Degrees of freedom for the $\mathrm{F}$ statistics are given by the deflators in the nominator and denominator of the $\mathrm{F}$ statistics. From the table of Model 2 we can see that the business cycle was in favor of Macedonia's' export from 1999 to year 2003. Most favorable countries for Macedonian products are: Bulgaria, Croatia and Greece. And Target countries GDP and Population significantly affect volume of exports from Macedonia to other target Balkan countries.

\section{The effects of explanatory variables}

Macedonia's' domestic variables exert negative and significant relationship with the supply of exports. Local country GDP (Macedonia's' GDP) is a measure of the size of the domestic economy in terms of available goods. Target GDP is a measure of the extent that exports are "sucked" in as economy grows. Target GDP is positively and statistically significant. On the other hand population of the target country exerts negative and statistically significant coefficient. 


\section{Random effect results}

a) The static model

Next in a Table is presented RE result for the gravity model. In this part we use FGLS estimator and panel IV estimator.

Model 3. FGLS and Panel IV $\beta_{1}, \gamma_{j}, \lambda_{t} \neq \mathbf{0}$ for all $\mathbf{i}, \mathbf{j}$, and $\mathbf{t}$

\begin{tabular}{lcc}
\hline & FGLS & IV \\
& Parameter estimate \\
POPjt & $-0.00309381 * * *$ & $-.00303236 * * *$ \\
POPit & $-0.72891223 * * *$ & $-.85905251 * * *$ \\
Yit & $0.01726893 * * *$ & $0.01994611 * * *$ \\
Yjt & $0.0003559 * * *$ & $0.00034557 * * *$ \\
ERij & $-11.449321 * *$ & -5.0446842 \\
cons & & \\
$\bar{R}^{2}$ & $1319.9327 * * *$ & $1547.7278 * * *$ \\
\hline
\end{tabular}

legend: $* \mathrm{p}<0.05 ; * * \mathrm{p}<0.01 ; * * * \mathrm{p}<0.001$

From this table we can see that IV estimates in fixed and random effects model are similar except for the sign on the $\mathrm{POP}_{i t}$ variable which in $\mathrm{RE}$ model is negative.

b) Dynamic model

In the next table we will present dynamic model GMM type Arellano-Bond dynamic panel-data estimation and inconsistent OLS which is included just for comparison. 
Model 4. Dynamic model : Arellano-Bond dynamic panel-data estimation and OLS inconsistent $\beta_{1}=\gamma_{j}=\lambda_{t}=0$

\begin{tabular}{lcc}
\hline & $\begin{array}{c}\text { Arellano-Bond } \\
\text { dynamic panel- }\end{array}$ \\
& $\begin{array}{c}\text { OLS } \\
\text { data estimation }\end{array}$ \\
& \multicolumn{2}{c}{ Parameter estimate } \\
Lxtij & $0.76867208^{* * *}$ & $0.55998265^{* * *}$ \\
POPjt & -0.00483955 & - \\
& & $0.00177683^{* * *}$ \\
& & \\
POPit & $-0.32269152^{*}$ & -0.19494174 \\
Yit & $0.01071575^{* *}$ & 0.00814804 \\
Yjt & 0.00018865 & $0.00020856^{* * *}$ \\
ERij & 7.4502591 & $-6.415409^{*}$ \\
cons & $583.57586^{*}$ & 324.48307 \\
$\bar{R}^{2}$ & n.a & 0.61702463 \\
Test for & & \\
autocorrelation (at & 0.3544 & \\
1 lag) p-value & & \\
Sargan test for & & \\
overidentifying & & \\
restrictions & & \\
(Ho : & & \\
overidentifying & & \\
restrictions are & & \\
valid).p-value & & \\
\hline
\end{tabular}

legend: * $\mathrm{p}<0.05 ; * * \mathrm{p}<0.01 ; * * * \mathrm{p}<0.001$

As expected, lagged values of the dependent variable are positive and statistically significant. Test for autocorrelation proved that this is not a problem at 1 lag neither is at 2 or three lags. 
Sargan test for overidentifying restriction proved that former are valid but the explanatory power of the model is weak because we have 102 degrees of freedom. 


\section{Discussion}

In the models in all of them domestic country GDP is positively correlated with the exports from the source country to target countries. This applies also for source country GDP when regressed with source country exports'. In addition, lagged values of source country's' exports are positively correlated with source country's' exports. The dummy variables model showed that Balkan countries have positive propensities to import from Macedonia especially Bulgaria and Greece, although National bank statistics showed that Serbia and Montenegro received most fo the Macedonian exports. Bulgaria and Greece are part of EU so Macedonia could benefit with exporting in the two countries.

Populations of source country and target country are negatively correlated with exports from the source country to target countries. Real exchange rate between countries $\mathrm{i}$ and $\mathrm{j}$ in year $\mathrm{t}$, is insignificant or in Feasible Generalized squares model is negatively significantly correlated with the source country exports. The dummy variables models where dummy variables were used for the business cycles, to capture the business cycle effect showed that in contrast to the base year (1994) all the years from 1995 to 2006 was negative for Macedonian export. This means that business cycles during this period compared to 1994 or before that year had no positive effect on Macedonian export to the target countries.

As conclusion it is evident that Macedonian export is mostly sent to Balkan countries. First, because the distance is not so considerable, and second, because of the cultural similarities in terms of similar language barriers and mentality of the traders. Indeed, Macedonia could further benefit through deepening ties with present partners as the processes of EU accession advances. 


\section{References:}

Anderson, J. E. 1979. A Theoretical Foundation for the Gravity Equation. The American Economic Review, 69(1): 106-116.

Anderson, J. E., \& Wincoop, E. v. 2003. Gravity with Gravitas: A Solution to the Border Puzzle. The American Economic Review, 93(1): 170-192.

Baier, S. L., \& Bergstrand, J. H. 2007. Do free trade agreements actually increase members' international trade? Journal of International Economics, 71(1): 72-95.

Deardorff, A. V., \& Research, N. B. o. E. 1995. Determinants of bilateral trade: does gravity work in a neoclassical world?: National Bureau of Economic Research.

Decker, J., \& Lim, J. 2009. Democracy and trade: an empirical study. Economics of Governance, 10(2): 165-186.

Dellas, H., \& Ben-Zion, Z. 1993. Real Exchange Rate Volatility and International Trade: A Reexamination of the Theory. Southern Economic Journal, 59(4): 641-647.

Dollar, D., \& Kraay, A. 2003. Institutions, trade, and growth. Journal of Monetary Economics, 50(1): 133-162.

Evenett, Simon J., \& Keller, W. 2002. On Theories Explaining the Success of the Gravity Equation. Journal of Political Economy, 110(2): 281-316.

Frankel, J. A. 2008. The Estimated Effects of the Euro on Trade: Why Are They Below Historical Effects of Monetary Unions Among Smaller Countries? National Bureau of Economic Research Working Paper Series, No. 14542. 
Frankel, J. A., \& Romer, D. 1999. Does Trade Cause Growth? The American Economic Review, 89(3): 379-399.

Freinkman, L. M., Polyakov, E., \& Revenco, C. 2004. Trade performance and regional integration of the CIS countries: World Bank.

Grauwe, P. 1996. International money: postwar trends and theories: Oxford University Press.

Grauwe, P. D. 1988. Exchange Rate Variability and the Slowdown in Growth of International Trade. Staff Papers - International Monetary Fund, 35(1): 63-84.

Helpman, E., \& Krugman, P. R. 1987. Market structure and foreign trade: increasing returns, imperfect competition, and the international economy: MIT Press.

Helpman, E., Melitz, M., \& Rubinstein, Y. 2008. Estimating Trade Flows: Trading Partners and Trading Volumes. The Quarterly Journal of Economics, 123(2): 441-487.

IMF. 2012. International Monetary Fund's Direction of Trade Statistics (DOTS)

Martinez-Zarzoso, I. 2003. Gravity model: An application to trade between regional blocs. Atlantic Economic Journal, 31(2): 174-187.

Meeusen, W. 1999. Economic policy in the European Union: current perspectives: Edward Elgar.

NBRM. 2012. National Bank of the Republic of Macedonia Statistics.

Rodrik, D. 2002. Trade Policy Reform as Institutional Reform. In B. M. Hoekman, A. Mattoo, \& P. English (Eds.), 'Development, trade, and the WTO: a handbook': 3-10. Washington, DC: World Bank. 
Tinbergen, J. 1962. Shaping the world economy: suggestions for an international economic policy: Twentieth Century Fund.

Williamson, J. 1983. The exchange rate system Institute for International Economics, Washington, $D C$ 